\title{
Effects of anti-clay agents on fresh and hardened properties of concrete containing clay
}

\author{
Yue $\mathrm{Li}^{1}$, S.M.Ali S.Hejazi ${ }^{1, *}$, and Han $\mathrm{Kun}^{1}$ \\ ${ }^{1}$ The Key Laboratory of Urban Security and Disaster Engineering, MOE. Beijing University of Technology, 100124, \\ China
}

\begin{abstract}
In this paper, four kinds of agents (2000 polyethylene glycol (pg2000), aminosalicylicacid (ASA), saodium alginate (SA), sodium metasilicate anhydrous (SMA)) were investigated as potential anticlay agents combined with polycarboxylate water reducer (PCE), and the fluidity, compress strength, and flexural strength of cement paste, mortar, and concrete containing aforementioned anti-clay agents were tested. It found that among the tested potential anti-clay agents, PG2000 have performed well. The fluidity of the concrete with PG2000 increased 16mm compared to the control sample. In order to understand the mechanisms underlying this improvement, X-ray Diffraction(XRD) of cement paste was carried. The results show PG2000 has the highest interlayer spacing $(\mathrm{d}=2.865142 \mathrm{~nm})$ compare with control sample $(\mathrm{d}=2.828410 \mathrm{~nm})$ (not added PG2000), which make it more effective on the fluidity of concrete.
\end{abstract}

\section{Introduction}

Ongoing fast growth of the constructions worldwide has run into huge consumption of resources. As one of the examples these days, there is a limitation in the use of high quality aggregates which can result in higher expenditures during the projects [1]. In recent years, with the rapid increase in the amount of infrastructure projects, the annual consumption of sand and gravel is large, leading to quality throughout the year [2-4]. There are fewer and fewer sandstone resources, and the mud content in the sandstone is high. The high mud content in the aggregate will not only reduce the strength and workability of the concrete, but also increase the shrinkage of the concrete [5].

Generally, in concrete mixing stations, the amount of sand and gravel is usually more than 5\%, and some sandstones contain up to $10 \%$ of mud [6]. In this way, sandstone raw materials in most areas are still in short supply [7]. When the mud content in concrete is high, the polycarboxylate water reducer (PCE) exhibits insufficient water reduction rate and the slump loss of concrete is large[8].In this project, four types of anti-clay agents are investigated with respect to their effects on freshening and hardening properties of the concrete which contains mud based on the test results, the best anti-clay agent among four different agents was selected and the achievements of this study will be useful for increasing the quality of concrete in construction projects.

\section{Test conditions}

\subsection{Materials and mix ratio}

\subsubsection{Cement}

The cement used in this project is P.O 42.5 cement, and its basic physical properties are shown in table 1, which meets the requirements of current national standards.

\subsubsection{Aggregate and Polycarboxylate water reducer (PCE)}

The coarse aggregate is $5-16 \mathrm{~mm}$ gravel with apparent density $2680 \mathrm{~kg} / \mathrm{m}^{3}$. The fine aggregate is medium sand with the fineness modulus is 2.6. The water reduction rate of PCE is $27 \%$.

\subsubsection{Montmorillonite(MMT)}

MMT was used as mud and its chemical compositions is shown in table 2. A two-layer silicon ox tetrahedral wafer and a layer of aluminum octahedral wafer form a unitary crystal layers, and the upper and lower surfaces of the unit crystal layer are all oxygen atoms, which can adsorb equal-charged cations or hydration cations. MMT connected by intermolecular forces, weak connection between the layers.

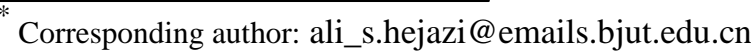


Table1. Basic properties of cement

\begin{tabular}{|c|c|c|c|c|c|c|c|c|}
\hline \multirow{2}{*}{$\begin{array}{l}\text { Fineness } \\
\left(\mathrm{m}^{2} / \mathrm{kg}\right)\end{array}$} & \multirow{2}{*}{$\begin{array}{l}\text { Density } \\
\left(\mathrm{kg} / \mathrm{m}^{3}\right)\end{array}$} & \multirow{2}{*}{$\begin{array}{c}\text { Water } \\
\text { consumption } \\
\text { of normal } \\
\text { consistency } \\
(\%)\end{array}$} & \multirow{2}{*}{$\begin{array}{l}\text { Initial } \\
\text { setting } \\
\text { time } \\
(\mathrm{min})\end{array}$} & \multirow{2}{*}{$\begin{array}{l}\text { Final } \\
\text { setting } \\
\text { time } \\
(\mathrm{min})\end{array}$} & \multicolumn{2}{|c|}{$\begin{array}{c}\text { Compressive } \\
\text { strength }\end{array}$} & \multicolumn{2}{|c|}{ Flexural strength $(\mathrm{MPa})$} \\
\hline & & & & & $3 d$ & $28 d$ & $3 d$ & $28 \mathrm{~d}$ \\
\hline 334 & 3105 & 26 & 204 & 267 & 27.5 & 56.2 & 5.4 & 10.2 \\
\hline
\end{tabular}

Table 2. Chemical compositions of MMT.

\begin{tabular}{llllllllll}
\hline & Loss & $\mathrm{SiO} 2$ & $\mathrm{Al} 2 \mathrm{O} 3$ & $\mathrm{Fe} 2 \mathrm{O} 3$ & $\mathrm{SO} 3$ & $\mathrm{CaO}$ & $\mathrm{MgO}$ & $\mathrm{K} 2 \mathrm{O}$ & $\mathrm{Na} 2 \mathrm{O}$ \\
\hline $\mathrm{Mt}(\mathrm{wt} \%)$ & 9.10 & 64.80 & 16.53 & 2.58 & 0.02 & 2.03 & 4.04 & 0.55 & 0.16 \\
\hline
\end{tabular}

\subsubsection{Anti-clay agents}

Four kind of anti-clay agents used in this experiment;1)2000 Polyethylene glycol(Pg2000),2) Amino salicylic acid(ASA),3) Sodium Metasilicate Anhydrous(SMA), 4) Sodium Alginate(SA).<smiles>COCCCO</smiles><smiles>NOC(=O)C1OC(O)C(O)C(O)C1O</smiles>

2000Polyethyleneglycol<smiles>Nc1ccc(C(=O)O)c(O)c1</smiles><smiles>[NH3+][Si](=O)O[Na]</smiles>

Sodium Alginate Sodium Metasilicate Anhydrous

Fig.1. Chemical structure of anti-clay agents

\subsection{Design of cement mortar and concrete specimen}

\subsubsection{Specification of cement mortar}

The mix design of cement mortar is shown in Table 3. As can be seen from Table 3 , the fluidity of cement mortar was significantly reduced after adding MMT, and the reduction rate reached $21.5 \%$. Presence of clay minerals in coarse and fine aggregates can have remarkable effects on the workability of fresh concrete, effectiveness of chemical admixtures, and on the mechanical strength, dimensional stability and durability of hardened concrete.

\subsubsection{Determination fluidity of cement mortar}

Based on the mixing ratio of mortar No. 2 in table 3 , four kinds of anti-mud agents were added to cement mortar. The results are shown in table 4.

The addition of PG2000 are $0.5 \%, 1.2 \%$, and $1.8 \%$ by the mass of the clay, respectively. The mixing ratio 0 and test results of mortar are shown in table 5.

According to the test results of cement mortar in table 5, it's obvious that by adding Pg2000 in mix proportion it makes the fluidity much more than that of control sample.

\subsubsection{Test results of concrete with PG2000}

In order to evaluate the actual effects on concrete, $1.8 \%$ PG2000 was chosen because of its best performance on fluidity in cement mortar in Table 5. The mix design and test results of concrete were shown in Table 6.

According to the data above in table 6 could easily find out that by adding $1.8 \%$ of $\mathrm{Pg} 2000$, slump of concrete determines an increase from $107 \mathrm{~mm}$ on control to $123 \mathrm{~mm}$ on adding PG2000 sample.

\section{XRD}

Montmorillonite has a certain layer spacing.

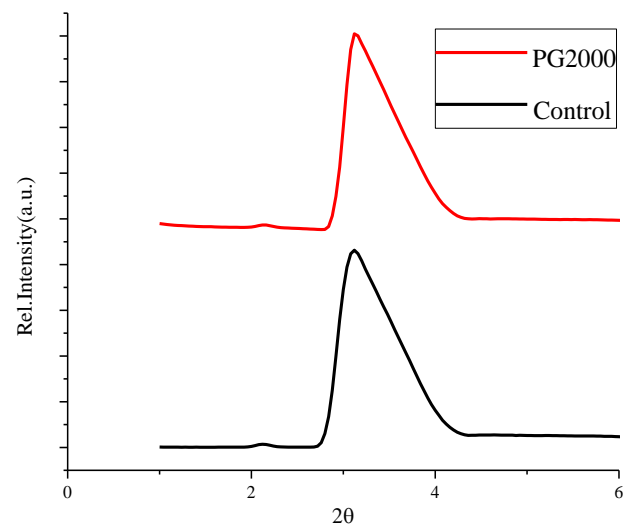

Figure 2. XRD patterns of cement paste with PG2000 (red) and Control (black)

Therefore, it is possible to determine whether there is intercalation adsorption by detecting changes in the 
interlayer distance, and XRD analysis was performed for cement paste shown in Table 7.

The interlayer spacing was monitored using X-ray diffraction to analyze the peak according to Bragg's Law $(2 \mathrm{~d} \sin \theta=\mathrm{n} \lambda)$. XRD measurements were carried out with $\mathrm{Cu} \mathrm{K} \alpha$ radiation $(40 \mathrm{kV}, 40 \mathrm{~mA}$.). $\theta$ for control sample is 1.54 so according to Bragg's Law interlayer spacing is $\mathrm{d}=2.828410 \mathrm{~nm}$, hence $\theta$ for $\operatorname{Pg} 2000$ sample is 1.56 so $\mathrm{d}=2.865142 \mathrm{~nm}$. (Figure 1). For control sample (cement paste without anti clay), we found that after mixing MMT and PCE, the layer spacing was significantly larger than the layer spacing of MMT(d 1,3nm). For the reason that PCE was inserted between MMT layers, which increased the MMT layer spacing. After adding PG2000, d increased, which indicated that PG2000 was inserted between the layers of montmorillonite and replaces PCE, so that the adsorption amount of PCE on montmorillonite was reduced.

Therefore, more PCE was adsorbed on the cement particles, which improved the fluidity.

\section{Conclusions}

Among the tested anti clay agents, PG2000 performed well. The fluidity of PG2000 concrete improved by
$16 \mathrm{~mm}$ compared to the control sample. In order to understand the underlying mechanisms of this progress, we used X-ray powder diffraction (XRD) cement paste. The results show that PG2000 has the highest interlayer spacing $(\mathrm{d}=2.865142 \mathrm{~nm})$ compare with control sample $(\mathrm{d}=2.828410 \mathrm{~nm})$, which makes it more effective in the fluidity of the compound. Our study shows that adding anti clay agents with specific microstructures to concrete is an efficient way to enhance its fluidity while maintaining mechanical properties and improving it to some extent.

Successful selection of agents will have many promises in real engineering, reduce the cost of heavy treatment and thus reduce the total cost of concrete engineering.

\section{Acknowledgement}

The authors would like to acknowledge the financial support provided by National Key R\&D Program of China-Key materials and preparation technology of high crack resistant ready-mixed concrete (2017YFB0310100), National Natural Science Foundation of China (51678011).

Table 3. Cement mortar mix proportion

\begin{tabular}{ccccccc}
\hline Samples & water & cement & aggregates & $\begin{array}{c}\text { PCE proportion } \\
\text { by mass of } \\
\text { cement } \%\end{array}$ & $\begin{array}{c}\text { MMT } \\
\text { Proportion by } \\
\text { mass of } \\
\text { aggregates } / \%\end{array}$ & Fluidity(mm) \\
\hline 1 & 0.35 & 1 & 1.5 & 0.3 & - & 256 \\
\hline 2 & 0.35 & 1 & 1.5 & 0.3 & 0.7 & 200.5 \\
\hline
\end{tabular}

Table 4. Effect of four anti-clay agents on the fluidity of cement mortar

\begin{tabular}{|c|c|c|c|c|}
\hline \multirow[t]{2}{*}{ Sample } & & \multicolumn{3}{|c|}{ Fluidity/mm } \\
\hline & & $5 \mathrm{~min}$ & $15 \mathrm{~min}$ & $30 \mathrm{~min}$ \\
\hline Control & & 200.5 & 186.5 & 176 \\
\hline $\begin{array}{c}\text { Type of anti-clay } \\
\text { agent }\end{array}$ & $\begin{array}{c}\text { Addition }=\text { Weight of clay } \\
\times(\text { value }) \%\end{array}$ & & & \\
\hline \multirow[t]{6}{*}{ PG2000 } & 0.2 & 202 & 187.5 & 171 \\
\hline & 0.5 & 211 & 197 & 187 \\
\hline & 0.8 & 202.5 & 193 & 176.5 \\
\hline & 1.1 & 199 & 184.5 & 170 \\
\hline & 1.4 & 205 & 191 & 180 \\
\hline & 1.8 & 210 & 190.5 & 180 \\
\hline \multirow[t]{2}{*}{ ASA } & 1.2 & 190 & 175 & 160 \\
\hline & 1.6 & 205 & 184 & 170 \\
\hline \multirow{4}{*}{ SMA } & 0.5 & 184.5 & 170 & 151 \\
\hline & 1.0 & 196.5 & 183 & 175.5 \\
\hline & 1.5 & 195 & 182.5 & 170 \\
\hline & 2 & 193 & 172.5 & 159.5 \\
\hline \multirow[t]{2}{*}{ SA } & 0.2 & 195 & 179 & 163 \\
\hline & 0.4 & 193.5 & 177.5 & 162 \\
\hline
\end{tabular}


Table 5. The physical and mechanical properties of mortar with PG2000

\begin{tabular}{cccccccc}
\hline Sample & PG2000 & Slump5min & $\begin{array}{l}\text { Slump30 } \\
\text { min }\end{array}$ & 3d Compress & $\begin{array}{l}28 \mathrm{~d} \\
\text { compress }\end{array}$ & $\begin{array}{c}3 \mathrm{~d} \\
\text { Flexural }\end{array}$ & $\begin{array}{l}28 \mathrm{~d} \\
\text { Flexural }\end{array}$ \\
\hline Control & 0 & 237 & 222 & 33.4 & 43.88 & 5.69 & 7.43 \\
\hline 1 & $0.5 \%$ & 252 & 235 & 31.88 & 49.64 & 4.96 & 8.77 \\
\hline 2 & $1.2 \%$ & 258 & 243 & 31.2 & 41.66 & 5.07 & 8.65 \\
\hline 3 & $1.8 \%$ & 265 & 250 & 30.97 & 35.6 & 4.68 & 7.2 \\
\hline
\end{tabular}

Table 6. Mix proportion of concrete and its test results

\begin{tabular}{|c|c|c|c|c|c|c|c|c|c|c|c|}
\hline samples & $\begin{array}{l}\text { Water } \\
\mathrm{kg}\end{array}$ & $\begin{array}{c}\text { Cement } \\
\mathrm{kg}\end{array}$ & $\begin{array}{c}\text { sand } \\
\mathrm{kg}\end{array}$ & $\begin{array}{c}\text { gravel } \\
\mathrm{kg}\end{array}$ & $\begin{array}{l}\mathrm{PCE} \\
\mathrm{kg}\end{array}$ & $\begin{array}{l}\text { MMT } \\
\mathrm{kg}\end{array}$ & $\begin{array}{l}\mathrm{A} . \\
\mathrm{C} \\
\mathrm{kg}\end{array}$ & $\begin{array}{l}\text { SLUMP } \\
(\mathrm{mm})\end{array}$ & $\begin{array}{c}\text { SLUMP } \\
\text { ONE } \\
\text { HOUR } \\
(\mathrm{mm})\end{array}$ & $\begin{array}{c}\text { COMPRE } \\
\text { SS } \\
\text { STRENGT } \\
\text { H (MPa) } \\
\text { 3DAYS }\end{array}$ & $\begin{array}{c}\text { COMPRES } \\
\text { S } \\
\text { STRENGT } \\
\text { H (MPa) } \\
\text { 28DAYS } \\
\end{array}$ \\
\hline Control & 4.22 & 15.13 & $\begin{array}{c}19.3 \\
4\end{array}$ & 22.25 & $\begin{array}{c}0.10 \\
8\end{array}$ & 0.16 & - & 107 & 58 & 37.95 & 44.1 \\
\hline $\begin{array}{l}1.8 \% \mathrm{~A} . \\
\mathrm{C}\end{array}$ & 4.22 & 15.13 & $\begin{array}{c}19.3 \\
4\end{array}$ & 22.25 & $\begin{array}{c}0.10 \\
8\end{array}$ & 0.16 & $\begin{array}{l}0 . \\
28\end{array}$ & 123 & 97 & 37.75 & 38 \\
\hline
\end{tabular}

Table 7. Cement paste mix proportions for PG2000 and Control sample for XRD

\begin{tabular}{ccccr}
\hline Sample & Water(gr) & MMT(gr) & Anti-clay agent(gr) & PCE(gr) \\
\hline Control & 115 & 10.8 & 0 & 2.25 \\
\hline PG2000 & 115 & 10.8 & 0.1944 & 2.25 \\
\hline
\end{tabular}

\section{References}

1. M.L. Nehdi. (2013). Clay in cement-based materials. Construction and Building Materials, 51 (2014) 372-382

2. Ayati, B., Ferrándiz-Mas, V., Newport, D., \& Cheeseman, C. (2018). Use of clay in the manufacture of lightweight aggregate. Construction and Building Materials, 162, 124-131.

3. S. Ng, J. Plank, Interaction mechanisms between $\mathrm{Na}$ montmorillonite clay and MPEG-based polycarboxylate superplasticizers, Cem. Concr. Res. 42 (6) (2012) 847-854.

4. Courard, L., Michel, F., \& Pierard, J. (2011). Influence of clay in limestone fillers for selfcompacting cement based composites. Construction and Building Materials, 25(3), 1356
5. D. Atarashi, K. Yamada, A. Itoh, M. Miyauchi, E. Sakai, Interaction between montmorillonite and chemical admixture, J. Adv. Concr. Technol. 13 (6) (2015)325-331.

6. M. Chi, R. Huang, Effect of montmorillonite as additive on the properties of cement-based composites, Sci. Eng. Compos. Mater. 19 (1) (2012) 45-54.

7. H. Tan, C. Qi, B. Ma, X. Li, S. Jian, Effect of polycarboxylate superplasticiser adsorption on fluidity of cement-clay system, Mater. Res. Innov. 19 (S5) (2015) 423-428.

8. Gowripalan N, Sirivivatnanon V, Lim C C. Chloride diffusivity of concrete cracked in flexure[J]. Cement and Concrete Research, 2000, 30(5), 725730 